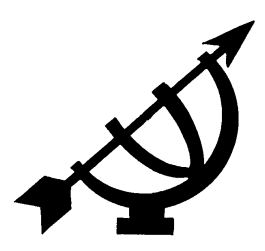

\title{
Biodiversity and environmental education: A contradiction?
}

\author{
J.G. Ferreira \\ Department Further Teacher Education \\ University of South Africa \\ PRETORIA \\ E-mail: ferrejg@unisa.ac.za
}

\begin{abstract}
Biodiversity and environmental education: A contradiction?

The need for the maintenance of biodiversity has become a much-debated environmental concern. However, calling for continued biodiversity exposes one to potential accusations of caring more for the natural environment than for people. This article briefly reviews the development of environmental education and provides an overview of the concepts "biodiversity", "sustainable development" and "sustainable consumption". Reasons for maintaining biodiversity while simultaneously allowing for sustainable development and sustainable consumption are considered, but the main purpose of the article is to raise questions about current environmental education practice in South Africa and whether the concern of biodiversity is in actual fact addressed.
\end{abstract}

\section{Introduction}

All over the world pleas are heard for maintaining biodiversity, while at the same time ensuring sustainable development and allowing for equally sustainable consumption (Andrzejewska, 1998:431). It is, however, not possible to meet these pleas without environmental education. The only way to stress the value of maintaining biodiversity in a hungry world is through education. How else could one convey the message of why pristine environments should be maintained as such, when there is a shortage of land? How else can people understand the need for spending vast amounts on conservation, if they themselves are jobless? Who should be responsible for educating and informing people? Is that not the task of environmental educators? Have environmental educators acknowledged the need for biodiversity or have they merely concentrated on matters that are in line with existing trends? Countries that are rich in 
biodiversity have become targets of so-called bioprospectors and often these are developing countries which are not able to exploit the potential of their own resources (Gubb, 2001:5). Besides concentrating on empowerment and improving people's quality of life, should environmental education not also address the need for biodiversity? If this is so, or if we claim that we do, has this been the main focus of environmental education in the past decade?

During the past few decades environmental education in South Africa has undergone some change in approach and focus. To illustrate this point, a brief overview of the development of environmental education is provided. Subsequent to this, the concepts "sustainability", "biodiversity" and "sustainable consumption" are discussed, after which the question is raised as to whether current environmental education trends actually achieve what they are intended to achieve.

\section{Brief history}

Prior to the seventies, most education efforts linked to the environment concentrated on "conservation education", which addressed the conservation of the natural environment and elementary ecology (Ballantyne \& Uzzell, 1993:4). This one-sided approach, as well as the existing political situation in South Africa at the time, sparked a negative attitude towards conservation. The impression that people were mostly excluded from conservation areas; that they gained very little benefit from their establishment and the feeling that the areas were established at their own expense, contributed to this negativity. Conservation was viewed as a means to deprive people of their land for the sake of animals.

Environmental education as it is known today, had its origins in the early seventies when the International Union for the Conservation of Nature (IUCN) defined environmental education as follows:

Environmental education is the process of recognising values and clarifying concepts in order to develop skills and attitudes necessary to understand and appreciate the inter-relatedness amongst people, their culture and biological and physical surroundings. Environmental Education also entails practice in decision making and self formulation of behaviour about issues concerning environmental quality (IUCN, 1971).

This definition considered the development of skills and attitudes of people whereas the previous form of environmental education concentrated on the transference of knowledge about the natural environment. $A$ further significant change in the approach to environmental education which the IUCN definition raises, is the incorporation of people, their 
culture and their immediate physical surroundings which had previously been neglected. The empowerment of people by developing skills, particularly as regard decision-making, is an additional modification which contributed to the value of environmental education.

Towards the end of the seventies, the world's first Inter-governmental Conference on Environmental Education was held in Tbilisi. During the conference twelve guiding principles for environmental education were identified. The recommendations of this conference were acknowledged by the United Nations Educational, Scientific and Cultural Organisation (UNESCO 1980:2).

The principles were used as a starting point for environmental education throughout the world and reiterated the difference between environmental education on the one hand, and conservation or ecology education on the other. During the past two decades, numerous philosophies and approaches to environmental education have evolved and because environmental education is dynamic, further new developments are inevitable.

Environmental education has been viewed as a means to bring about political and social change in South Africa (Bak, 1995:10). Consequently, economic empowerment and the improvement of the quality of life of previously disadvantaged communities, receive priority, but what about "biodiversity" and "sustainability"? These two key words became the buzz-words after the Earth Summit in Rio de Janeiro in 1992. The central agreement, after intense discussion, became known as Agenda 21, the world agenda for the twenty-first century.

Tema (1999:224) makes the claim that prior to the happenings in Rio, the main scope of environmental education veered towards the conservation of the natural environment. Environmental education had poor links with the various dynamic systems that existed in society, namely the economic, cultural, political, religious, social, scientific and technological systems. The emphasis was on the environment, and human quality of life and sustainability, in a pragmatic manner, hardly featured. However, during the Earth Summit in 1992 the concept of "sustainable development" came under the spotlight creating the opportunity to change the focus of environmental education. What exactly was meant by sustainability and sustainable development?

\section{Sustainable development}

According to Shiva (1991:192) the real meaning of sustainability refers to nature's and people's sustainability. It basically involves a recovery of the 
realisation that nature supports our lives and livelihoods and is the primary source of sustenance. Consequently, sustaining nature implies maintaining the integrity of nature's processes, cycles and rhythms; sustainable development is about staying within the resources of the planet whilst improving the quality of human life. The term "sustainability" originated from ecology, denoting the conditions required for ecosystems to be sustained in the long term (Naess, 1995:121), but means different things to different people. For some, it implies the protection of biodiversity (Basiago, 1995:110); for others it is a strategy to address past injustices through sustainable development, and yet for others it is a means to achieve.

Sustainable development is difficult to grasp as it covers a wide field, such as social, economic and cultural issues, the natural and physical environments and their interrelationships (Tema, 1999:221). It is viewed as a means to improve the living standards of people without eroding the economic base on which they depend. Tema (1999:22) goes on to say that sustainable development is "development which addresses the needs of the present generation while it simultaneously secures survival and a good, healthy environment for the future generations". This definition of sustainable development is very similar to that of "conservation" as, proposed by the IUCN and quoted by Fourie and Rust (1999:8), namely "... the management of human use of the biosphere so that it may yield maximum sustained benefit to present generations, whilst maintaining its ability to meet the needs and aspirations of future generations". This raises the questions as to whether sustainable development and conservation are, in fact, synonymous.

Arguments have been raised that sustainable development is productive as it allows for discussion between economy and the environment, but Flogaitis (1998:191) maintains that its acceptance by business, industry and political interests (which are in fact the pioneers of non-sustainability) is questionable. Sustainable development is considered as a ploy from the side of business and developmental parties to thwart confrontation between ecological balance and economic developments and between the interests of the affluent and the poor. This suggests that sustainable development serves as an instrument for the maintenance of business development and not of the natural environment. Consequently, the concept "sustainable development" can be interpreted in a way that serves two opposing ideals: on the one hand, it ensures development without jeopardising the future supply of resources, but on the other, it could be used to cloud judgement and result in exploitation.

Sustainable development does not mean that there should be no human impact whatsoever on the environment as this is impossible. The ideal 
though, is a situation in which all environmental impacts are undertaken with the full knowledge of the costs and implications, even if these would only become relevant in the distant future. The best way to address this would be to evaluate natural systems in economic terms. We need to realise that humans are a part of nature and the natural environment, not separate of or in opposition to it. The continuance of human life depends upon our ability to abstain from destroying the natural systems which regenerate the planet. In this regard, Haralambous (1998:241) claims that the development process in developing countries could lead to tremendous environmental degradation due to poverty and underdevelopment. Poor rural people are often forced to ecological margins to earn their livelihood and have no alternative but to over-exploit the resources they have. They usually do not have enough land to make a living and maintain sustainable practices. This is relevant to the South African situation. The limited available land, as well as meagre subsistence farming, have resulted in pressure on the environment.

A key issue regarding sustainable development boils down to the role of economic growth (the quantitative expansion of economies) and economic development (the qualitative improvement of society) (Middleton, 1995:288). In its first report, the World Commission on Environment and Development (WCED, 1987) indicated that sustainability could only be achieved if the world economic activity increased five- to tenfold within fifty years. This growth would be essential if the basic needs of the larger future population are to be met. The same commission has since changed its stance somewhat and played down the importance of growth (WCED, 1992). This is due to different reactions to pleas for sustainability, namely to concentrate on growth as usual though at a slower rate, or to consider sustainable development as development without growth in throughput beyond environmental capacity. Growth should therefore be achieved by better use of resources and improved environmental management (Middleton, 1995:289).

\section{Sustainable consumption}

The concept "sustainable consumption" is also a product of the 1992 Earth Summit and may seem like a contradiction in terms. It was asserted at the Summit that unsustainable patterns of consumption and production, particularly in the industrialised world, are the major causes of continuing environmental degradation. Furthermore, achieving the goals of sustainable development will require efficiencies in production and change in consumption patterns in order to emphasise optimisation of resource use and minimisation of wastes. Production, which is the role of industry, raises images of pollution, chemical waste dumped in rivers and landfill sites. Production, however, also leads to increased comfort in 
life. How does one convince people to change the way in which they consume to avoid unacceptable impacts on the environment and society if they have to sacrifice certain comforts?

One approach to addressing sustainable consumption, is simply to acknowledge that there is too much consumption and to attempt to reduce the level of consumption. For some people this approach may seem ideal, but it ignores the central role of consumption in driving the global economy in bringing about development. This approach would have to impose heavy constraints on consumption choices and would probably not be acceptable in democratic systems. It would also not be fair to instruct the developing world that they cannot have the improved quality of life enjoyed by the Western world.

Eppel (1998:258) suggests that the real challenge of sustainable consumption is to change patterns of consumption without reducing the individual's quality of life and still respecting individual choices and ambitions. The change to more sustainable production and consumption will involve modification to business operations, but also education. People who are on the brink of being compensated for deprivations are suspicious of approaches calling for a simpler life with decreased consumerism. This is in contrast to what is expected and may be considered as an attempt to withhold the acquisition of material goods. A further cause for suspicion is the support of environmental education by developed countries, which may have hidden agendas for underdeveloped countries (Bak, 1995:10). Here again, the motive behind sustainability and development is questioned.

\section{Biodiversity}

The concept "biodiversity" has become a much-debated environmental concern. The term refers to the number, variety and variability of living organisms and is commonly defined in terms of genes, species and ecosystems (Middleton, 1995:86). The key issue at stake in the biodiversity debate is its loss which can take many forms, the ultimate of which is the extinction of species. Extinction is a natural process and this is substantiated by fossil evidence. Most people are familiar with the most recent mass extinction event 65 million years ago when dinosaurs were eradicated! However, there is concern that another mass extinction event is on the cards; one which is induced by the earth's human population.

Middleton (1995:92) mentions that the two ends of the spectrum of arguments in favour of conserving biodiversity are rooted in morality and pragmatism. Some people are of the opinion that the destruction of any 
living organism is morally unacceptable and that people have no right to threaten the survival of any such organism. The pragmatic approach points out that the extermination of any organism is not in the interest of people. Middleton (1995:92) claims that biodiversity is useful to humankind in the wide perspective, in maintaining the biosphere as a functioning system and, at a functional level, in providing resources for agriculture, industry, medicine and other needs. The converse is, however, applicable when pests associated with disease are considered. These are exterminated on purpose to ensure the health of the inhabitants of the planet.

Human activities are integrally bound up in a world ecosystem. To avoid impending disaster, sensible measures like conserving ecosystems or allowing for the development of more of them, would at least stabilise plant and animal diversity. However, in addition to these measures, sensitivity towards the needs of plants and animals should be increased so that they can continue to live and reproduce in the wild. Surely this is a task for environmental education.

Conflict between the aims of conservation and consumption has existed for a long time, but it has become obvious that conservation cannot succeed without the input and involvement of local people in the design and management of protected areas. Bodies with the authority and ability to enforce regulations have often been responsible for enforcing conservation without involving these people and this has resulted in antagonism. This again, reiterates the importance of environmental education.

\section{Environmental education}

Environmental education in South Africa used to focus on nature conservation, but progressively values and environmental principles have been incorporated to address environmental concerns such as pollution and waste management. In some sectors the original interpretive approach has not changed, but in most environmental education has become strictly anthropocentred and has tended to neglect the maintenance of biodiversity. It has recognised the pragmatic imperative that basic human needs and the process of redressing poverty are the first issues to be tackled. Those who reject an instrumentalist interpretation of environmental education do so from a philosophical perspective and consider environmental education for sustainability as "embodying an impoverished world view in that it reduces environmental considerations to issues of efficiency and maximization of use" (Bak, 1995:16). Sustainability induces a formal business attitude and a conception that nature is a collection of resources. These differing ideas 
as to what environmental education should entail are based on values and principles used by people in a variety of contexts and on different positions in environmental ethics. Is environmental education currently based on an ethic that forms values, develops skills and builds capacity to allow for sustainability and the maintenance of biodiversity?

Environmental ethics should guide the practical enterprise of environmental decision-making, policy-formation, management an education. However, as environmental ethics do not speak with one, single coherent and internally consistent voice (Hattingh, 1999:55), there is no clear-cut guideline to influence environmental decision-making and environmental education. The ultimate challenge of environmental ethics, however, as stated by Rolston (1991:92), is the conservation of life on earth through the development of a value theory that will enable people to identify environmentally safe forms of production and consumption.

Leff (1998:174) refers to the various positions within environmental ethics as "ecosophies" and mentions that they range from intensive ecology and biocentrism to social ecology. Hattingh (1999:56) describes six distinct positions of ethics, namely the "ethic" of the ruthless developer, resource conservation and development, wilderness preservation, ethical extensionism, ecological sensibility and radical environmental ethics, which encompasses different perspectives of which social ecology is one. Social ecology has become the value theory of environmental education in South Africa. This is based on the fact that most environmental educationists at present are of the opinion that social problems have to be addressed before ecological problems could be considered. A further substantiating point is the establishment of a Department of Social Ecology in the South African National Parks in the nineties. The basis for this approach lies in the argument that people will only be able to live in harmony with nature and ecological systems if they adopt and engage in self-determining activities. These developments have resulted in an approach to environmental education in which biodiversity is hardly addressed and the other extreme of the continuum is over emphasised.

Many environmental educationists will probably contend that the preceding discussion is an overly simplistic view as to what environmental education in South Africa has entailed or should entail. Others may assert that sustainability and biodiversity are addressed adequately in the diverse programmes on offer, but are these truly reflected in all forms of environmental education in this country? The State of the Environment Report for South Africa (Department of Environmental Affairs and Tourism, 1999) addresses both sustainability and biodiversity and shows how these concerns are linked. This Report addresses an entire environmental picture and does not highlight one trend at the expense of 
another. Should a concerted effort not be made to do the same in all environmental education endeavours? Is it not time for introspection and reassessment of environmental education practice?

It may be necessary to take a step back and thoroughly consider what is done at present and what should be done in future. This exercise should not only result in a reassessment of programmes on offer, but should also ascertain whether environmental education is doing what it is supposed to do.

\section{Closing remarks}

The purpose of the preceding discussion is to raise questions about existing environmental education endeavours in South Africa. The Earth summit in 1992 identified "sustainable development", "sustainable consumption" and "biodiversity" as key issues that had to be addressed. These issues changed the approach to environmental education throughout the world, but the political changes in South Africa required that environmental education should concentrate particularly on social issues, through social ecology. The fact that most people were excluded from past conservation practices has cast the maintenance of biodiversity in a negative light. Consequently, although "sustainability" and "sustainable development" have been considered, albeit with reservation, the value of the maintenance of biodiversity has been neglected. The result is that proponents of biodiversity are viewed as opposers to sustainability and sustainable development.

It is hoped that even if the focus in the preceding discussion is not supported, environmental educators would be encouraged to assess the various positions to environmental ethics; reconsider their approach; raise questions as to what they wish to achieve and ascertain whether they are in fact doing so. As custodians of earth, we have a responsibility to our Creator to do so.

\section{Bibliography}

ANDRZEJEWSKA, L. 1998. The need of ecological education for conservation and restoration of the natural environment. (In Environment and society: Education and public awareness for sustainability. Proceedings of the Thessaloniki International Conference, 8-12 December 1997. Athens : UNESCO and the Government of Greece. p. 431-434.)

BAK, N. 1995. Tensions exist in environmental education. Bulletin - News for the Human Sciences: 10,16, Dec/Jan.

BALLANTYNE, R.R. \& UZZELL, D. 1993. Environmental mediation and hot interpretation: A case study of District Six, Cape Town. Journal of Environmental Education, 24(3):4-7. 
BASIAGO, A.D. 1995. Methods of defining "sustainability". Sustainable Development, 3(3):109-119.

DEPARTMENT OF ENVIRONMENTAL AFFAIRS AND TOURISM (DEAT). 1999. State of the environment - South Africa. Pretoria : DEAT.

EPPEL, J. 1998. Education for sustainable consumption. (In Environment and society: Education and public awareness for sustainability. Proceedings of the Thessaloniki International Conference, 8-12 December 1997. Athens : UNESCO and the Government of Greece. p. 255-260.)

FLOGAITIS, E. 1998. The contribution of environmental education in sustainability. (In Environment and society: Education and public awareness for sustainability. Proceedings of the Thessaloniki International Conference, 8-12 December 1997. Athens : UNESCO and the Government of Greece. p. 189-193.)

FOURIE, J. \& RUST, I. 1999. An introduction to nature guiding. Cape Town : Gloriosa Nature Company.

GUBB, A. 2001. Bioprospecting - the genetic gold rush. African Wildlife, 55(4):5.

HARALAMBOUS, S. 1998. Sustainable livelihoods for the rural poor in marginal areas. (In Environment and society: Education and public awareness for sustainability. Proceedings of the Thessaloniki International Conference, 8-12 December 1997. Athens : UNESCO and the Government of Greece. p. 241-245.)

HATTINGH, J. 1999. Are we there yet? Taking stock of three decades of environmental ethics. Paper delivered at the Environmental Education Association of Southern Africa Conference, 7-10 September 1999, Grahamstown.

INTERNATIONAL UNION FOR THE CONSERVATION OF NATURE (IUCN). 1971. Education and the environment. Papers of the Nevada Conference of 1970 and the Zurich Conference of 1971. Morges : IUCN Publication Series.

IUCN

see INTERNATIONAL UNION FOR THE CONSERVATION OF NATURE

LEFF, E. 1998. Environmental education and sustainable development. (In Environment and society: Education and public awareness for sustainability. Proceedings of the Thessaloniki International Conference, 8-12 December 1997. Athens : UNESCO and the Government of Greece. p. 173-176.)

MIDDLETON, N. 1995. The global casino: An introduction to environmental issues. London : Edward Arnold.

NAESS, P. 1995. Central dimensions in a sustainable urban development. Sustainable Development, 3(3):120-129.

ROLSTON, H. 1991. Environmental ethics. Values in and duties to the natural world. (In Bornmann, F.H. \& Kellert, S.R., eds. The broken circle: Ecology, economics, ethics. New Haven : Yale University Press. p. 73-96.)

SHIVA, V. 1991. The real meaning of sustainability. (In Cooper, D. \& Palmer, J., eds. The environment in question: Ethics and global issues. London : Routledge. p. 190-204.)

TEMA, W.T. 1999. From environmental education to education for sustainable development: A transitional growth. Paper delivered at the Environmental Education Association of Southern Africa Conference, 7-10 September 1999, Grahamstown.

UNESCO

see UNITED NATIONS EDUCATIONAL, SCIENTIFIC AND CULTURAL ORGANISATION

UNITED NATIONS EDUCATIONAL, SCIENTIFIC AND CULTURAL ORGANISATION (UNESCO). 1980. Environmental education in the light of the Tbilisi conference. Paris : UNESCO. 
WCED

see WORLD COMMISSION ON ENVIRONMENT AND DEVELOPMENT

WORLD COMMISSION ON ENVIRONMENT AND DEVELOPMENT (WCED). 1987.

Our common future. Oxford: Oxford University Press.

WORLD COMMISSION ON ENVIRONMENT AND DEVELOPMENT (WCED). 1992.

Our common future reconvened. London : WCED.

\section{Key concepts:}

biodiversity

environmental education

sustainability

sustainable consumption

\section{Kernbegrippe:}

biodiversiteit

omgewingsopvoeding

volhoubaarheid

volhoubare verbruik 
